\title{
URBAN LAND ECONOMICS
}


By the same author

BASIC ECONOMICS

BASIC ECONOMICS WORKBOOK

ELEMENTARY ECONOMICS

WORKBOOK FOR ELEMENTARY ECONOMICS

INTERMEDIATE ECONOMICS

MULTIPLE CHOICE QUESTIONS FOR

INTERMEDIATE ECONOMICS

THE BRITISH CONSTITUTION (with L. Bather)

HOW BRITAIN IS GOVERNED

WORKBOOK FOR HOW BRITAIN IS GOVERNED

PRODUCING AND SPENDING (With M. Harvey)

MODERN ECONOMICS

MODERN ECONOMICS STUDENT'S NOTEBOOK

MODERN ECONOMICS: STUDY GUIDE

AND WORKBOOK (with M. K. Johnson)

INTRODUCTION TO MACRO-ECONOMICS (with M. K. Johnson)

INTRODUCTION TO MACRO-ECONOMICS:

AWORKBOOK (with M. K. Johnson)

GOVERNMENT AND PEOPLE (with $M$. Harvey)

THE ORGANISATION IN ITS ENVIRONMENT

THE ORGANISATION IN ITS ENVIRONMENT:

ASSIGNMENTS FOR BEC COURSES (with J. Chilver)

MASTERING ECONOMICS

ECONOMICS REVISION GUIDE 


\title{
URBAN LAND ECONOMICS
}

\author{
Fourth Edition
}

Jack Harvey

B.Sc. (Econ.), Dip. Ed. (Oxford) 
(C) Jack Harvey 1981, 1987, 1992, 1996

All rights reserved. No reproduction, copy or transmission of this publication may be made without written permission.

No paragraph of this publication may be reproduced, copied or transmitted save with written permission or in accordance with the provisions of the Copyright, Designs and Patents Act 1988, or under the terms of any licence permitting limited copying issued by the Copyright Licensing Agency, 90 Tottenham Court Road, London W1P 9HE.

Any person who does any unauthorised act in relation to this publication may be liable to criminal prosecution and civil claims for damages.

First edition (published as The Economics of Real Property) 1981 Reprinted 1985, 1986

Second edition (published as Urban Land Economics) 1987

Reprinted 1988, 1989, 1990

Third edition 1992

Reprinted 1993, 1994

Fourth edition 1996

Published by

MACMILLAN PRESS LTD

Houndmills, Basingstoke, Hampshire RG21 6XS

and London

Companies and representatives

throughout the world

ISBN 978-0-333-65439-2 ISBN 978-1-349-24441-6 (eBook)

DOI 10.1007/978-1-349-24441-6

A catalogue record for this book is available from the British Library.

$\begin{array}{llllllllll}10 & 9 & 8 & 7 & 6 & 5 & 4 & 3 & 2 & 1\end{array}$

$\begin{array}{llllllllll}05 & 04 & 03 & 02 & 01 & 00 & 99 & 98 & 97 & 96\end{array}$ 
I am the basis of all wealth, the heritage of the wise, the thrifty and prudent. I am the poor man's joy and comfort, the rich man's prize, the right hand of capital, the silent partner of many thousands of successful men.

I am the solace of the widow, the comfort of old age, the cornerstone of security against misfortune and want. I am handed down to children, through generations, as a thing of greatest worth.

I am the choicest fruit of toil. Credit respects me. Yet I am humble. I stand before every man, bidding him know me for what I am and possess me.

I grow and increase in value through countless days. Though I seem dormant, my worth increases, never failing, never ceasing, time is my aid and population heaps up my gain. Fire and the elements I defy, for they cannot destroy me.

My possessors learn to believe in me; invariably they become envied. While all things wither and decay, I survive. The centuries find me younger, increasing with strength.

The thriftless speak ill of me. The charlatans of finance attack me. I am trustworthy. I am sound. Unfailingly I triumph and detractors are disproved.

Minerals and oils come from me. I am producer of food, the basis for ships and factories, the foundation of banks.

Yet I am so common that thousands, unthinking and unknowingly, pass by me.

I am land.

Lou Scott, What is Real Estate? 


\section{Contents}

Preface to the First Edition xii

Preface to the Second Edition xiv

Preface to the Third Edition xv

Preface to the Fourth Edition xvi

Acknowledgements xvii

\section{PART I WELFARE AND ECONOMIC EFFICIENCY}

1 Economic Efficiency Through the Price System 3

1.1 Welfare and economic efficiency 3

1.2 Conditions necessary for Pareto optimality 4

1.3 Achieving the conditions of economic efficiency 9

1.4 Conditions necessary for economic efficiency through the price system 12

\section{PART II REAL PROPERTY}

$2 \quad$ Characteristics of the Real Property Market 19

2.1 Is there a real property market? 19

2.2 The efficiency of the real property market 22

3 Functions of the Real Property Market 26

3.1 Dealings in real property interests 26

3.2 Functions of the real property market 27

$4 \quad$ The Pricing of Land and Land Resources 33

4.1 Land as a whole 33

4.2 The commercial rent of land 34

4.3 The pricing of land resources 38

4.4 The dominance of stocks over flows 39

$5 \quad$ Investment in Real Property 45

5.1 Investment characteristics of different interests in real property $\quad 45$

5.2 Investors in real property $\quad 50$ 
5.3 The overall level of yield on investment assets in general

5.4 The pattern of yields on different assets with particular reference to property assets

5.5 Asset yields over time; an empirical study

5.6 The effect on the real property market of the demand for land resources as an investment

\section{PART III DEVELOPMENT}

6 The Development Process

6.1 The nature of development 71

6.2 Problems of the developer 73

6.3 Choosing between capital projects 76

6.4 Estimating demand $\quad 82$

6.5 Optimum construction outlay 86

6.6 The intensity of site use $\quad 88$

6.7 The amount which can be paid for the site $\quad 89$

6.8 The choice of development project 92

7 The Tuming and Rate of Redevelopment 93

7.1 The timing of redevelopment 93

7.2 The rate of redevelopment 97

$8 \quad$ Finance for Development 102

8.1 General considerations $\quad 102$

8.2 Short-term finance 104

8.3 Long-term finance 106

9 Comprehensive Redevelopment 112

9.1 The nature of comprehensive redevelopment $\quad 112$

9.2 Comprehensive redevelopment by private enterprise

9.3 Redevelopment by the local authority 115

9.4 Partnership arrangements between local authorities and private developers

10 Public-sector Development: Cost-benefit Analysis

10.1 The functions of cost-benefit analysis (CBA) 119

10.2 The principles of CBA 121

10.3 The problem of distributional effects $\quad 127$

10.4 Adjusting market prices $\quad 128$

10.5 Pricing non-market goods 130

10.6 Dealing with spillover effects and intangibles 134

10.7 Choosing the appropriate discount rate 137

10.8 An appreciation of the role of CBA 141 
10.9 Cost-benefit studies of the New Covent Garden Market

11 The Economics of Planning Controls 147

11.1 Introduction 147

11.2 Externalities 149

11.3 The rationale of planning controls $\quad 154$

11.4 The impact of planning controls 162

12 The Construction Industry 166

12.1 The nature of the construction industry 166

12.2 The conditions of demand and supply in the construction industry $\quad 168$

12.3 Pricing the product 172

12.4 The structure of the construction industry 175

12.5 Builders' merchants 177

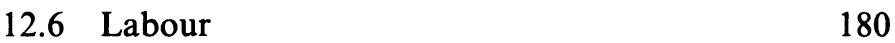

12.7 Productivity 182

12.8 Mechanisation 182

12.9 Innovation 186

12.10 Mass production $\quad 189$

12.11 The current situation and prospects 193

PART IV URBAN LAND USE

13 Land Use and Land Values 197

13.1 Introduction 197

13.2 Transport costs and location 199

13.3 Factors determining urban land use $\quad 202$

13.4 Government policy 206

13.5 A generalised presentation of location choice $\quad 209$

14 The Pattern of Urban Land Use 215

14.1 Application of the Von Thunen model 215

14.2 Theories of urban structure 223

15 The Growth of Urban Areas 229

15.1 Theories of urban growth 229

15.2 The urban hierarchy and central place theory $\quad 235$

15.3 Optimum city size 238

15.4 The problem of 'overspill' $\quad 240$

15.5 Green belts 243

15.6 New towns 244

15.7 Expanded towns 247 
16 The Quality of the Urban Environment:

Problems of Urban Areas

16.1 Urban decay 251

16.2 Pollution 258

16.3 Conservation 263

16.4 Urban traffic 268

17 Housing 278

17.1 The provision of housing through the price system 278

17.2 Housing policy 281

17.3 The economics of rent control 285

17.4 Rent control and changes in tenure distribution 288

17.5 The 1979 policy watershed 293

17.6 The impact of Thather policies on tenures 298

17.7 The collapse of the housing market 307

18 Regional Policy 312

18.1 The regional problem $\quad 312$

18.2 The location of industry in its regional context

18.3 Theories and models of regional growth 318

18.4 Government policy 321

18.5 Urban regeneration 327

18.6 Regional policy in the context of the EU 329

PART V THE GOVERNMENT AND LAND RESOURCES

19 The Impact of Government Economic Policy

Objectives on Land Resources

19.1 Introduction 333

19.2 Stability of the economy 334

19.3 The policy of land nationalisation 338

20 Theory of Urban Public Finance 341

20.1 The provision of goods and services by the public sector 341

20.2 Public-sector expenditure 344

20.3 Financing public-sector services 345

20.4 User-charges 346

20.5 Taxation 350

$21 \quad$ The Incidence of Taxation on Land Resources 357

21.1 Introduction 357

21.2 General direct taxation and land resources 
21.3 The application of VAT to real property 363

21.4 Local property taxes $\quad 365$

21.5 Present finance of local government 373

21.6 The future of local finance 376

22 Recent Developments $\quad 378$

22.1 The property market: from boom to collapse $\quad 378$

22.2 Repercussions of the property collapse 383

22.3 The EU and the property industry 389

Recommended Reading 394

$\begin{array}{ll}\text { Index } & 397\end{array}$ 


\section{Preface to the Furst Edition}

In recent years much attention has been directed to the nature of our environment in its various aspects - town planning, adequate open spaces providing recreational and cultural facilities, housing, inner-city decay, pollution, noise, architectural harmony, conservation, and so on. Our environment today is the result of a combination of economic, sociological, aesthetic and political influences. This book concentrates on the economic factors which have to be taken into account. While it recognises the importance of the other influences, its central theme is that, instead of economics being relegated to a secondary role often called upon to appraise and analyse only after basic decisions have been taken, the economist should be integrated into the decision-making process from the beginning, for his approach is of vital importance.

Since land and buildings are scarce resources, it is essential that they are used as efficiently as possible. This is the starting-point of the economist, and his task is, by applying economic analysis, to formulate principles necessary for the efficient use of land resources and thereby to suggest ways in which the existing allocation might be improved.

Thus the book follows the accepted procedure of first building abstract models, from which are derived the essential conditions for the efficient allocation of resources, and then proceeds to examine the assumptions which are essential for this most efficient situation to be achieved. Using this theoretical analysis, it goes on to consider how, in the British context, the conclusions derived from the model can be applied to the allocation of real property resources - land and buildings.

In Britain's mixed economy real property resources are mainly distributed by market forces. Initially, therefore, the book examines the market solution, its strengths and weaknesses, both in the way in which it functions and the institutions through which it works. Subjects covered are the nature of the market, the determination of real property prices, investment in real property assets, property development in both the private and public sectors, the construction industry and housing policy. 
While passing references are made to possible government adjustments to the market solution, the main discussion of government policy is reserved for the final chapter. This considers the impact on land resources of government macro policy and the strengths and weaknesses of influencing the allocation of resources through taxation and subsidies, planning controls and public ownership. It must be emphasised, however, that the economist can only define the economic issues involved. For instance, he is limited in what he can say about the redistributive, sociological, aesthetic and even the political effects. Different strategies have different economic results - and while the economist can indicate these, the final choice of policy must rest with the politician.

Although the emphasis is on theoretical economic analysis, the discussion is made as practical as possible by being conducted in the context of the real property market in Britain and by being supplemented by empirical studies and selected statistics.

The main aim of the book is to provide a text for the student following courses in estate management, surveying, valuation, town planning, housing administration, geography and environmental subjects. While it does assume some knowledge of basic economic theory, this is no more than is required for most first-year courses for professional examinations. But the book should be of interest to those already actively engaged in professions relating to the land, in that it demonstrates how economics can provide a useful tool in the solution of practical problems. More hopefully, where decisions are subject to or are influenced by politicians or public administrators, it is trusted that what economics reveals may cause them to reflect on the full implications of their selected policies.

Of the many people - fellow-lecturers and students - who have contributed to the ideas expressed in this book, the outstanding influence has been the late Professor F. G. Pennance, a pioneer in applying economic analysis in the field of land use. He is remembered as a true friend and a wise counsellor, always encouraging, suggesting improvements and offering penetrating criticism and alternatives, backed by a sound professional training and long experience in teaching. Many past students of the College of Estate Management, the University of Reading and the University of Aberdeen who had the privilege of attending his tutorials must, like me, now appreciate the contribution which sound economics can make to the principles which should guide the improvement of our environment. 


\section{Preface to the Second Edition}

The scope of the book, as reflected in its new title, has been extended to cover the syllabuses of the main professional bodies and degree courses in land and property economics. Eight new chapters deal with the economics of planning controls, land use and land values, the pattern of urban land use, the growth of urban areas, the quality of the environment, regional policy, the background to urban public finance and the incidence of taxation on land resources. In addition, facts and institutional changes have been brought up to date.

Ideas for improvement from many readers have been incorporated in this new edition, but I would like to acknowledge the particular debt I owe to Dr M. Oxley, Principal Lecturer, Leicester Polytechnic, for his careful reading of the proofs and his many helpful and constructive suggestions.

J. H. 


\section{Preface to the Third Edition}

Facts have been brought up to date and recent changes in institutions have been incorporated in the text. But major changes in the UK economy have had pronounced effects on the real property market during the last decade; to cover these, I have considered that the most satisfactory course was to provide an additional final chapter (Chapter 22). Rather than 'sit on the fence', I have allowed some of my own views to intrude in the section on 'the crisis in real property'.

J.H. 


\section{Preface to the Fourth Edition}

In this edition, facts have been brought up to date and the text revised to cover recent changes in UK institutions and government policy.

However, since the approach is still basically the application of economic analysis to urban land problems, overseas students should have little difficulty in relating the theory to the institutions and conditions peculiar to their own country.

Chapters 17 (housing) and 22 (recent developments) have been extensively re-written.

In general more emphasis has been given to the extent to which current government policy with regard to the problems of urban areas conforms to economic theory.

J. H. 


\section{Acknowledgements}

The author and publishers wish to thank the Controller of HMSO for permission to reproduce extracts from official publications, and also Allsop \& Co. for permission to include Table 5.2. 